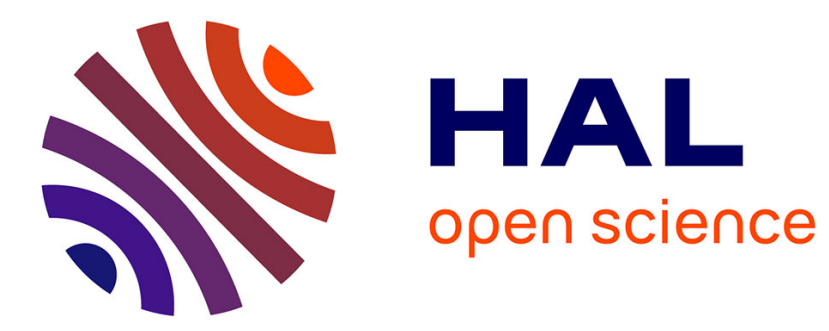

\title{
Knowledge in economics and economic reform : an analysis of French survey data
}

\author{
Radu Vranceanu, Jérôme Barthélemy
}

\section{To cite this version:}

Radu Vranceanu, Jérôme Barthélemy. Knowledge in economics and economic reform: an analysis of French survey data. 2011, pp.24. hal-00592114

\section{HAL Id: hal-00592114 \\ https://essec.hal.science/hal-00592114}

Submitted on 11 May 2011

HAL is a multi-disciplinary open access archive for the deposit and dissemination of scientific research documents, whether they are published or not. The documents may come from teaching and research institutions in France or abroad, or from public or private research centers.
L'archive ouverte pluridisciplinaire HAL, est destinée au dépôt et à la diffusion de documents scientifiques de niveau recherche, publiés ou non, émanant des établissements d'enseignement et de recherche français ou étrangers, des laboratoires publics ou privés. 


\title{
Knowledge in economics and economic reform : An analysis of French survey data
}

\author{
Research Center \\ ESSEC Working Paper 1103 \\ January 2011
}

Radu Vranceanu

Jérôme Barthélémy 


\title{
KNOWLEDGE IN ECONOMICS AND ECONOMIC REFORM: AN ANALYSIS OF FRENCH SURVEY DATA
}

\author{
Radu Vranceanu and Jerome Barthelemy \\ ESSEC Business School, 95021 Cergy, France
}

20.01.2011

\begin{abstract}
The coexistence of a predominantly poor opinion of free markets and lack of education in economics are two documented features of France. In this paper, we use data collected through an Internet-based survey conducted in December 2009 in order to test whether this situation is more than a mere coincidence. A first regression model allows us to study how personal characteristics, general and economics education, occupation and personal interest in economics affect knowledge in economics. We then apply factor analysis in order to build an aggregate indicator of opinion on promarket reforms. This opinion indicator becomes the dependent variable in a second multiple regression model; it turns out that knowledge in economics contributes by $3.5 \%$ to explain the favorable opinion on pro-market reforms.
\end{abstract}

JEL Classification: A11; A14; A20; C83

Key words: Economic knowledge, Policy reform, Survey methods, France.

Emails: vranceanu@essec.fr, barthelemy@essec.fr 


\section{KNOWLEDGE IN ECONOMICS AND ECONOMIC REFORM: AN ANALYSIS OF FRENCH SURVEY DATA}

\section{Introduction}

A critical attitude to capitalism and free markets is an established feature of French society. In June to October 2009, GlobeScan conducted a survey for the BBC World Service of more than 29000 persons all around the world. Although dissatisfaction with capitalism was generally on the rise after the last financial crisis, the survey highlighted huge differences between countries when it comes to opinions of free market capitalism. While less than $13 \%$ of respondents in Germany, Japan and the United States agreed that "capitalism is fatally flawed, and a new economic system is needed", $43 \%$ of the French ticked the "yes" box. ${ }^{1}$ Many other similar surveys performed in the last decade reached a similar outcome. The Economist on July $24^{\text {th }}, 2010$ notices that "Nowhere is contempt for free enterprise, and its linked evils of wealth and profits, more intense than in France". ${ }^{2}$ Criticism of free market capitalism is even louder among the cultural elite in which journalists, artists, and academics play a central role. It is not easy to see where this skepticism comes from, given that capitalism has put France among the leading Western economies, with per-capita GDP of $\$ 32,800$ in 2009 , and eighth in the world for total GDP (\$2.1 trillion), immediately after Germany, UK and Russia.

This resistance to reform has been part and parcel of the French social landscape for more than two centuries. The Ancien Regime's failure to modernize culminated in 1776 when King Louis XVI dismissed his finance minister, Anne Robert Turgot (Dakin, 1936), who was a proponent of free market reforms. Some could argue that the inability to reform, casting

\footnotetext{
${ }^{1}$ See for instance the BBC report on November 9, 2009 at http://news.bbc.co.uk/2/hi/8347409.stm.

2 Europe's dark secret, The Economist, July $24^{\text {th }}, 2010$, pg. 26.
} 
most of the population into poverty, and the massive indebtedness of the central government were what ultimately made recourse to violent changes unavoidable (French Revolution, 1789). In literature and philosophy, writers from Molière, Balzac and Zola to more recently Sartre have denounced the corrupting power of money.

In a recent theoretical paper, Saint-Paul (2010) submits an interesting explanation for modern France's persistent distrust of free markets. In his model, people who distrust markets self-select for the protected teacher profession; in this position, they do not have enough information to understand businesses and markets, and thus continue to relay a skeptical discourse on capitalism, further "indoctrinating" the next generation in a self-perpetrating anti-capitalist intellectual dynamic. However, as the author points out, this explanation cannot account for the negative attitude to markets of other intellectuals such as journalists, writers and artists who do not work in protected segments of the labor market. If the favorable/unfavorable opinion on free market capitalism cannot always be matched with a given profession, is there any other factor that can influence people's attitude toward promarket reforms?

The social science that studies voluntary exchange as a coordination mechanism is economics. Over the years, this discipline has evolved to become a consistent body of knowledge with significant explanatory power. In particular, by incorporating elements from statistics and game theory in the late 1970s, economics brought a fresh view about strategic decision-making under uncertainty. ${ }^{3}$ The other side of the coin is the extreme complexity of the field (Machlup, 1980), which makes correct analyses difficult for anyone without a minimum level of specific training.

It is perhaps unsurprising to learn that another salient feature of France is the low level of economic education and knowledge of economics. In a private remark extensively quoted

\footnotetext{
${ }^{3}$ See Blanchard (2009) for a survey of the recent advances and challenges of macroeconomics. See Vranceanu (2007) for a definition of economics with a focus on the ethical foundations of the field.
} 
by all French blogs on economics, Edmund S. Phelps, a respected winner of the Nobel Prize in economics, argued that if French people had a better education in economics, the country's potential output growth rate would increase by one percentage point. ${ }^{4}$ There is much to corroborate this challenging diagnostic. In 2007, the French Minister of Education ordered a report on economics as taught at secondary school level. Several international experts contributed to this document and an executive summary was drafted by Professor PierreAndré Chiappori from Columbia University. His conclusions were rather pessimistic, observing that French economics education neglects fundamentals. In addition, many French economics textbooks contain outright errors and biased representations of reality (ASMP, 2008). Several surveys performed since 2006 have also pointed out that many French people have difficulties with economic reasoning, and only modest knowledge of economic facts and institutions. ${ }^{5}$ Another survey showed that French people themselves believe that their general knowledge in economics is weak. ${ }^{6}$ Organizers of a national conference in Lyon in October 2009 on broad economic issues, attended by professional economists and policymakers, reported that: "In France, economics is hampered by a lack of understanding, knowledge diffusion and accessibility". ${ }^{7}$ Finally, international comparisons are also unfavorable to France with respect to economic literacy: Jappelli (2010) reports results on surveys on managers in various countries, performed by the IMD Lausanne and published in their World Competiveness Yearbook, who were asked how strong is economic literacy among the

\footnotetext{
${ }^{4}$ See Jean-Marc Vitori, L’inculture économique des Français, Les Echos, 03.06.2008.

${ }^{5}$ One survey on the knowledge of basic economic facts related to businesses (http://questionaire.fnege.org) was performed in September 2008 by the National Foundation for Management Education (FNEGE) on a representative sample of 1009 persons. The results were extremely disappointing. Another survey of basic economic knowledge - reasoning, facts, and practical use - was performed by a main French survey organization, the TNS-Sofres, in October 2009, at the demand of the CODICE (http://www.kezeco.fr/Passezvotre-test-Codice). The sample of 1080 persons was representative of the French population. Grades present a Gaussian distribution centered around 9.5/20. Somehow puzzling, the $64 \%$ of the respondents that never studied economics obtained an average grade as high as 8.4 .

${ }^{6}$ According to a survey carried out by the TNS-Sofress on behalf of the CODICE in November 2008.

7 “Les Journées de l'Economie de Lyon". See www.journeeseconomie.org.
} 
population. In 2008 France holds the 32th rank over 55 countries surveyed, far below the five leaders (Singapore, Finland, Hong Kong, Australia and Denmark).

To address the perceived weakness of general education in economics, the "Council for Diffusion of Economic Culture" (CODICE) was created in 2006 as a non-profit organization under the supervision of the Minister for Economics and Finance. In the initial Mission Letter, Thierry Breton, the incumbent minister, stated that: "French citizens have the right to get the skills needed to evaluate the economic decisions they will be subject to and to judge the economic plans that will be submitted to them.",8

We have so far argued that knowledge of economics is disappointing in France, and that the general opinion of free markets is rather negative. Some right-wing politicians argue that this is more than a coincidence, and that poor economics education could be responsible for the general skepticism about free markets. At least two distinct theories can back such a claim. If economics allows citizens to understand the true parameters of the economy and the relationship between markets and growth opportunities, this would naturally prompt them to endorse free-market reforms. In this 'optimistic' approach, market reforms are good for growth in general, but only the economically educated people know it. Political economy would provide a more 'pessimistic' explanation. If knowledge in economics is a proxy for human capital, and if market reforms favor reallocation of resources from the low skilled to the high skilled individuals, then the positive relationship between knowledge in economics and market reform would stem from selfish redistributive calculations (with winners from reform pushing for reform).

This paper aims at investigating the relationship between knowledge in economics and the social acceptability of pro-market reforms in France within an empirical set-up. In a first step, we examine the contribution of various factors to an individual's knowledge of

\footnotetext{
${ }^{8}$ See the Web site of the CODICE at www.codice.fr.
} 
macroeconomic principles and policies. In a second step, we explore the relationship between this measure of knowledge in economics and the attitude towards market-oriented reforms. For so doing, we work out an original indicator of opinion on market reforms that resorts to factor analysis in order to aggregate several dimensions. One key finding is that knowledge in economics has a substantial positive impact on the favorable opinion about pro-market reforms.

Data used in this paper were collected through an original Internet survey conducted in December 2009 by Vranceanu et al. (2010). The 1543 respondents belong to the network of a main French business school. With $90 \%$ of the respondents being graduates of higher education, this sample is representative of a group of highly educated persons, with current or future top positions in main French companies and organizations, including public administration and education. While the sample is not representative of the entire French population, previous studies suggest that education level has an influence on economic knowledge and economic opinion (Walstad and Rebeck, 2002). Therefore, testing the relationship between knowledge in economics and opinion on market-oriented reforms in a sample of highly educated people may be viewed as an "acid test": if a relationship can be put forward in this narrow segment of highly educated persons, it could probably be extended to other categories of people.

Our methodology builds to a large extent on a study by Walstad (1997) who used a set of US data collected by Gallup in 1992. His sample was made up of 1,005 randomly selected adults who answered 46 economic knowledge questions and gave their opinion on topical economic issues at that time: independence of the Fed, taxation, active labor market policies, controls on oil imports, tariffs. In a first step, the aggregate indicator of economic knowledge - defined as the proportion of right answers - was regressed on age, race, sex, college and high-school education in economics and income. In a second step, the author run five probit 
models, one for each policy issue. It turned out that economic knowledge has a significant impact on explaining opinions on the various issues. His findings were corroborated by Walstad and Rebeck (2002) who applied this methodology to similar US data collected by surveys in 1994, 1996, 1998 and 1999.

The paper is organized as follows. In the next section, we describe the data and the methodology. In the following section, we present our empirical findings. Finally, we discuss their implications.

\section{Data and sample}

A website was created specifically to host the web address of the test, describe the objective of the study, and explain the test procedure. ${ }^{9}$ The address was displayed on the homepage of the ESSEC Business School website for one full month, from December $1^{\text {st }}$ 2009 to January $5^{\text {th }} 2010 .^{10}$ All the partners and prospects, including high school pupils and undergraduates students who visited the Web site had direct access to the survey. In addition, the graduate students enrolled in the schools' programs, the staff and some of the close partners of the school (human resource managers in about 50 large firms) were invited by direct mails to fill the questionnaire. By January $5^{\text {th }} 2010,1,543$ persons had answered to all questions. ${ }^{11}$ The average answering time was 18 minutes.

The Introductory section contained questions such as age, gender, occupation, general education and education in economics. Additional questions asked how frequently the respondent uses economic concepts in daily life and whether the respondent has a personal

\footnotetext{
${ }^{9}$ The survey is available at https://sites.google.com/a/essec.edu/test_economie/. Special thanks to Delphine Dubart for the technical assistance in implementing the web questionnaire and database.

${ }^{10}$ ESSEC Business School is a well known French Business School. Students are admitted to prepare a graduate degree in management (three years) after passing a very demanding national competitive examination. They prepare for this competition during a two years specialized program.

${ }^{11}$ In total, 3617 persons have visited the website of the test. Those who dropped are much younger and less educated than the rest. This would support this idea according to which people who carried out the test did selfselect: only those that had a satisfactory education in economics went up to the end.
} 
interest for economic issues. For French-specific cultural reasons, it would have been inappropriate to ask questions about political orientation or income. Furthermore, it is illegal in France to ask questions about race or ethnic group.

The Test of Knowledge section contained 18 statements/questions. For each question, four true/false answers were submitted. Importantly, more than one answer could be true (which adds to the difficulty of the test). The focus of the survey was stated from the outset: macroeconomic and policy analysis as applied to the European and French context. Our questions draw from generally accepted principles in macroeconomics, such as presented in a majority of introductory textbooks and were validated by discussions with several economists. One important objective was to address ideology-free topics. ${ }^{12}$

Some of the questions tested the knowledge of elementary definitions (e.g., what is the GDP or the exchange rate), or the functioning of a key institution such as the European Central Bank. For instance, one question asked whether the main mission of the European Central bank is (a) to support the competiveness of European firms, (b) to maintain price stability, (c) to support the euro parity with respect to the dollar, or (c) to maintain public debt below a normal threshold. ${ }^{13}$ Most of the questions tested (macroeconomics) reasoning. For instance, it was asked whether a positive growth rate of the real GDP can be due to (a) higher inflation, (b) lower productivity, (c) an increase in employment or (d) technical progress. Another question asked whether during a recession the government decides to increase public spending, one can expect: (a) a reduction in public deficit due to higher tax revenues, (b) an increase in interest rates, (c) an increase in private investment, (d) a favorable effect on employment.

\footnotetext{
${ }^{12}$ This test of knowledge was worked out at ESSEC Business School by Radu Vranceanu and Maxime Laot.

${ }^{13}$ In December 2009 the answer was obvious. It might be less so now (late 2010), once that the Greek debt crisis has completely disturbed the principles agreed in 1992 (Maastricht Treaty).
} 
This definition of knowledge in economics is relatively narrow. It essentially captures the individual's knowledge of essential macroeconomic constructs and principles. ${ }^{14}$ The degree of difficulty of the test was adjusted to the minimum level required for a critical and autonomous analysis of economic policies. In this respect, the test can be considered as being rather difficult and success required a good background in economics. For sure, one should interpret results to such a test with extreme caution; this measure of "knowing economics" might be only imperfectly related to how much an individual really knows about the economy (Machlup, 1980).

Finally, a Reform opinion section was included at the end of the questionnaire with the aim of capturing the general sentiment of respondents on economic reforms. The attitude towards economic reform was measured using four three-point Likert scales:

1. In France, the role of the State as a provider of goods and services should: (a) increase, (b) be kept unchanged, (c) decrease.

2. The French layoff regulation should be: (a) made more flexible, (b) kept unchanged, (c) made stricter.

3. In France, economic reforms should: (a) go toward higher flexibility of the markets for goods and services, (b) not change the existing equilibrium, (c) go toward tighter regulation of the markets for goods and services.

4. In France, economic reforms should: (a) better protect enterprises, (b) not change the existing equilibrium, (c) enhance competition between firms.

\footnotetext{
${ }^{14}$ Economic knowledge can be seen as a broader concept that includes this definition of knowledge in economics and the knowledge of economic facts, institutions and challenges. See Blinder and Krueger (2004) for a nine item scale that aim at measuring directly economic knowledge. Examples of questions are: Do you know the level of the Federal budget deficit?" or "Do you know that President Bush had proposed partial privatization of Social Security?".
} 


\section{Empirical models}

\subsection{Factors affecting economic knowledge}

In the first regression model, the knowledge in economics test score was the dependent variable. Independent variables reflected personal characteristics, general education, economic education, occupation, personal interest for economic issues and the use of economic concepts in daily life.

As pointed out above, the knowledge in economics indicator reflects the percentage of correct answers to the 76 questions that were included in the survey. The score followed a normal distribution. For the sample of 1,543 respondents, the mean score was 71 percent correct. Only $8 \%$ of the respondents had a score better than $80 \%$. From the original 1,543 observations, 133 observations were dropped because of missing data. Thus, we were left with a sample of 1,410 observations.

The variables likely to influence knowledge in economics were all derived from prior US-based research (Walstad and Rebeck, 2002). The descriptions, means and standard deviations of these variables are presented in Table 1.

Insert Table 1 about here

According to Walstad (1997), economic knowledge should increase with age because older individuals have had more time to learn about economic phenomena than younger ones. On the other hand, one may expect younger individuals to be more knowledgeable in countries where the teaching of economics has improved in the last decades. In U.S. data, males have also been found to get higher scores than females on economic tests. Thus, the 
regression model includes a continuous measure of the age of the respondent (in years) and a dummy for the sex of the respondent.

The level of general education has also been found to influence knowledge in economics. Because respondents with more education are more literate, they are also more likely to be able to understand economic phenomena. In this study, we captured the level of general education using the following dummy variables: (1) high school education ("baccalauréat"), (2) two years of college ("baccalauréat+2"), (3) three years of college ("baccalauréat+3"), (4) four years of college ("baccalauréat+4"), (5) five years of college ("baccalauréat+5"), and (6) Ph.D ("doctorat"). In the regression analyses, high school education was the excluded category for this set of variables.

The level of economic education (i.e., if the respondent has studied economics as an independent course) is particularly likely to influence knowledge in economics. The higher the level of economic education, the better the expected level of knowledge in economics. Consistent with Walstad (1997), we captured prior course work in economics using two dummy variables: (1) high school economics only, and (2) college economics.

Income may also contribute to economic knowledge. As Walstad (1997, p.198) made clear: "Individuals with a higher level of income are more likely to show a direct interest in economic matters and are more likely to understand how the economy works than those with less income." In France however, people are very reluctant to disclose their income (even in anonymous surveys). Moreover, they have a negative perception about this question. As a proxy variable, we asked them for their current occupation using the following dummy variables: (1) executive, (2) employee, (3) self-employed, (4) professor, (5) student, and (6) other.

Finally, we asked the respondents about their personal interest for economics using a three point Likert scale ( 1 = "weak", 2 = "moderate", 3 = "strong") and their use of economic 
concepts in their daily life using a four-point Likert scale ( 1 = "never", 2 = "not very often", 3 = "very often", 4 = "all the time").

Table 2 summarizes the results of the OLS regression analysis.

Insert Table 2 about here

With an $\mathrm{R}^{2}$ as high as 0.27 , the explanatory power of the model is quite satisfactory. Overall, empirical results are consistent with prior U.S.-based studies (Walstad and Rebeck, 2002). Respondents are more likely to get a high score when they are males, more educated (cf. four years of college, five years of college and Ph.D.) and more trained in economics (cf. college economics).

Hence, if policymakers want to improve general economic knowledge of the populations, enhancing the volume and intensity of economic education is a good way to do so. We can notice that the coefficient on high school education is not significant, while the coefficient of college education is both large and statistically significant. The fact that the "high school" coefficient is not significant is consistent with the Chiappori Report (ASMP, 2008) that revealed major shortcomings in economics education at this level. This validates the decision of the government to focus his efforts on improving high school education in economics.

While occupation itself does not have a significant effect on knowledge in economics, it is interesting to notice that personnel interest for economics and the use of economic concepts in daily life also have a strong positive impact on knowledge in economics. 
The only significant difference with prior U.S.-based studies is that younger French people seem to have more knowledge in economics than older ones. This could be explained by the steady efforts made by successive governments to improve training in economics.

\subsection{Factors affecting attitude towards market-oriented economic}

\section{reforms}

In the second regression model, the attitude towards market-oriented economic reforms was the dependent variable and knowledge in economics was the main independent variable. All personal and educational characteristics from the first regression model were used as control variables.

While this technique is consistent with prior studies, our measure of the attitude towards market-oriented economic reforms is somewhat different. A priori, answers to the four opinion questions presented in the previous section are not likely to be correlated. In this case, the optimal strategy for analyzing the relationships between our measure of knowledge in economics and opinion answers would involve using four regression models. However, if individuals can be ranked according to their degree of economic liberalism, answers should be correlated. ${ }^{15}$ A liberal person, proponent of a small government and tougher competition in product and factor markets, fierce advocate of free trade, would pick answers 1-c, 2-a, 3-a and 4-c. The opposite would occur for the person that trusts the State for its ability of to correct market failures.

We thus apply factor analysis in order to check whether a common pattern can be inferred from the four pro-market reform opinion questions. This method is helpful for identifying patterns when several variables can be combined to measure an underlying (unobserved) construct (see for instance, Michael, 2000). Results are summarized in Table 3.

\footnotetext{
${ }^{15}$ There are many attempts to define economic liberalism, and it is beyond the scope of this paper to address this debate. An extremely sharp definition was conveyed by Milton Friedman in his Free to Choose masterpiece (Friedman, 1980).
} 
Using the standard criterion of eigenvalues superior to one, only one factor emerged from the analysis. This single factor explained $46 \%$ of the variance in the indicators. ${ }^{16}$ All indicators loaded with the same sign on the single factor, which confirms the interpretation of the factor as attitude towards economic reform. Hereafter, attitude towards free-market reform refers to the standardized factor score $($ mean $=0.00$ and standard deviation $=1.00)$.

Results of the regression analysis are summarized in Table 4.

Insert Table 4 about here

Model 1 includes only control variables. It is significant at the 0.01 level and explains $12.5 \%$ of the variance. General education, education in economics and personal interest for economics have all a positive statistically significant impact on the reform indicator. Man and older persons seem to be more favorable to free-market reforms. In general occupation is not statistically significant, although it might be interesting to notice the negative significant sign of the coefficient of the "employee" dummy variable. ${ }^{17}$

\footnotetext{
${ }^{16}$ The factor would have explained a higher percentage of the variance if we had used five-point or seven-point Likert scales for instance. Yet, when they have to take a stance about broad policy issues, people who can easily answer "more/less/unchanged", tend to be less at ease with five-point or seven-point scales.

${ }^{17}$ The "teacher" coefficient is negative, as suggested by Saint-Paul (2010) analysis, but it is not statistically significant neither in model 1 nor in model 2.
} 
The addition of the knowledge in economics variable significantly improves the $\mathrm{R}^{2}$ statistics from $12.5 \%$ to $16 \%$ (incremental $\mathrm{R}^{2}=0.035, \mathrm{p}<0.01$; the same variation for the adjusted $\mathrm{R}^{2}$ ). As expected, the sign of the regression coefficient on knowledge in economics is positive and strongly significant. The more respondents have knowledge in economics, the more they are likely to be in favor of pro-market economic reforms.

One may argue that our main result is driven by an omitted personality variable: those who believe in free-market capitalism simply like economics. Yet, we must emphasize that our result holds when we control for the personal interest for economics variable, which maintains its statistical significance in model 2. Furthermore, questions in the Test of Knowledge refer to definitions and principles in macroeconomics, among which the majority have a Keynesian flavor, a school of thought that is not the most favorable to free-market reforms. It is hard to see why those persons who can perform a correct Keynesian analysis should have a strong incentive to support free-market reforms.

Finally, as pointed out in the Introduction we noticed that those with a better knowledge in economics would support to market reforms either because they have a better understanding of the positive effects of these reforms, or because they have a better human capital and market reforms tend to redistribute resources from the low to the high skilled individuals. Our study corroborates both of these hypotheses. Indeed, the knowledge in economics indicator is positively related to the pro-market reform indicator while we control for general education (years of college), which is also statistically significant. General education is the best measure of human capital, and, as the "redistribution" assumption suggests, it is positively related to the favorable opinion on market reform. Given that knowledge in economics variable is positively related to the favorable opinion on market reform while we control for human capital, this would to corroborate the "better understanding" assumption. 


\section{Discussion and conclusions}

The effect of economic knowledge on economic reform opinions has been extensively explored in the US (Walstad and Rebeck, 2002). In this study, we focused on the influence of knowledge in economics on the attitude towards economic reform in France. The French context is particularly interesting because France is considered by a majority of analysts as particularly difficult to reform country. On the other hand, as pointed out in the Introduction, there is a widespread consensus among French policymakers (backed by opinion surveys conducted among the French citizens) that despites substantial interest of the French for economic issues, their general education in economics is relatively weak.

A first regression model showed that age, gender, general education, specific training in economics and personal interest for economics are important determining factors of economic knowledge.

In a second step, we apply factor analysis to build an original indicator of pro-market reform, using a four item scale. A second regression model showed that age, gender and general education have an impact on the reform indicator, as well as the personal interest for economics variable. The key finding is that the economic knowledge variable is positively related and contributes to explain $3.5 \%$ of the variance of the pro-reform indicator.

Since people with little knowledge in economics are more reluctant to economic change, then the ability of the French government to adopt more far-fetching economic reforms would increase if economics education improves. In the last few years the French government has taken several measures in order to improve high-school education in economics, by revamping curricula and textbooks. Our analysis suggests that this measure goes in the right direction. Indeed, from the data, high-school education in economics seems to be uncorrelated with our indicator of knowledge in economics. This can be the outcome of inadequate curricula, textbooks and training of the instructors. By comparison, college 
education in economics has a positive and statistically significant effect on knowledge in economics.

Saint-Paul (2010) argued that occupation should have an impact on the people's ability to understand the free market economy and ultimately on their political support for freemarket reforms. Our empirical findings point out that knowledge in economics could play a similar role. Indeed, we have shown that knowledge in economics and favorable opinions on free-market reforms are positively correlated while controlling for many other factors, including general education (as a proxy for human capital) and personal interest for economics. This empirical regularity suggests that economics might well help people understanding the functioning of the market economy, i.e., the world they live in. This is a major social goal, and policymakers might want to provide more resources to training people to this discipline, as they are trained to mathematics or literature.

Acknowledgments: The authors are grateful to Gilles Saint-Paul and Andrew Oswald for their suggestions and remarks on an early draft of this paper. 


\section{References}

ASMP, 2008, L'enseignement de l'économie dans les lycées, Academie des Sciences Morales et Politiques, see www.asmp.fr/travaux/gpw_enseignement_SES.htm.

Blinder, Alan S. and Alan B. Krueger, 2004, What does the public know about economic policy, and how does it know it?, NBER Working Paper 10787.

Blanchard, Olivier, 2009, The state of macro, Annual Review of Economics, 1, pp. 209-228.

Dakin, Douglas, 1939, Turgot and the Ancien Régime in France, London: Methuen.

FNEGE, 2008, La connaissance de l'entreprise par les français, On line at http://www.fnege.net/pdf/fnege-etude-entreprise.pdf.

Friedman, Milton, 1980, Free to Choose, University of Chicago Press.

Jappelli, Tullio, 2010, Economic literacy: An international comparison, Economic Journal, 120,548 , pp. 429-452.

Machlup, Fritz, 1980, Knowledge: its Creation, Distribution, and Economic Significance, Princeton University Press, Princeton.

Michael, Steven C., 2000, The effect of organizational form on quality: The case of franchising, Journal of Economic Behavior and Organization, 43, 3, pp. 295-318.

Saint-Paul, Gilles, 2010, Endogenous indoctrination: occupational choice, the evolution of beliefs, and the political economy of reform, Economic Journal, 120, 325-353.

Vranceanu, Radu, Maxime Laot and Delphine Dubart, 2010, Une échelle de mesure de la connaissance en raisonnement économique et résultats d'une enquête menée en Décembre 2009, ESSEC Working Paper, DR 10001.

Vranceanu, Radu, 2007, The moral layer of contemporary economics: a virtue-ethics perspective, In M.-L. Djelic and R. Vranceanu (Eds), Moral Foundations of Management Knowledge, Edward Elgar, Cheltenham, UK, pp. 134-158.

Walstad, William B. and Ken Rebeck, 2002, Assessing the economic knowledge and economic opinion of adults, Quarterly Review of Economics and Finance, 42, pp. 921935.

Walstad, William B., 1997, The effect of economic knowledge on public opinion of economic issues, Journal of Economic Education, Summer, pp. 195-205. 
Table 1: Description of dependent variables for economic knowledge regressions

\begin{tabular}{|c|c|c|}
\hline Variable & Mean & $\begin{array}{l}\text { Standard } \\
\text { deviation }\end{array}$ \\
\hline Percentage of correct responses on economic test & 71.480 & 10.207 \\
\hline \multicolumn{3}{|l|}{ General respondent characteristics } \\
\hline Age in years & 29.388 & 11.245 \\
\hline Respondent sex $(1=$ male; $0=$ female $)$ & 0.699 & 0.459 \\
\hline \multicolumn{3}{|l|}{ Level of general education $(1=$ yes; $0=$ no) } \\
\hline High school education & 0.099 & 0.299 \\
\hline Two years of college ('Baccalauréat + 2') & 0.132 & 0.339 \\
\hline Three years of college ('Baccalauréat + 3') & 0.091 & 0.287 \\
\hline Four years of college ('Baccalauréat + 4') & 0.106 & 0.308 \\
\hline Five years of college ('Baccalauréat + 5') & 0.511 & 0.500 \\
\hline Ph.D. ('Doctorat') & 0.060 & 0.238 \\
\hline \multicolumn{3}{|l|}{ Level of economic education $(1=$ yes; $0=$ no $)$} \\
\hline High school economics only & 0.106 & 0.308 \\
\hline College economics & 0.743 & 0.437 \\
\hline \multicolumn{3}{|l|}{ Personal interest for economics } \\
\hline 1 = "weak", 2 = "moderate", 3 = "strong" & 2.496 & 0.544 \\
\hline \multicolumn{3}{|l|}{ Use of economic concepts in daily life } \\
\hline $1=$ "never", 2 = "not very often", 3 = "very often", 4 = "all the time" & 2.182 & 0.874 \\
\hline \multicolumn{3}{|l|}{ Occupation $(1=$ yes; $0=$ no $)$} \\
\hline Executive & 0.350 & 0.477 \\
\hline Employee & 0.065 & 0.247 \\
\hline Self-employed & 0.030 & 0.172 \\
\hline Professor & 0.051 & 0.220 \\
\hline Student & 0.444 & 0.497 \\
\hline Other & 0.059 & 0.235 \\
\hline
\end{tabular}


Table 2: Results of knowledge in economics regression

Two-tailed tests. Standards errors are in parentheses. 
Table 3: Factor analysis of measures of attitude towards economic reform

\begin{tabular}{lc}
\hline Measures of attitude towards economic reform & Loading \\
\hline Change in the role of the State as provider of goods and services & 0.711 \\
Change in the flexibility of The French layoff regulation (reverse-coded) & 0.693 \\
Change in the flexibility of markets for goods and services (reverse-coded) & 0.608 \\
Economic reforms as a way to enhance competition between firms & 0.701 \\
\hline Eigenvalue & 1.848 \\
Variance explained $(\%)$ & $46.188 \%$ \\
\hline
\end{tabular}


Table 4: Results of attitude towards pro-market economic reforms regressions

\begin{tabular}{|c|c|c|}
\hline \multirow[t]{2}{*}{ Independent variables } & \multicolumn{2}{|c|}{ Estimated parameter coefficients } \\
\hline & Model 1 & Model 2 \\
\hline Constant & $\begin{array}{c}-1.483 * * \\
(0.270)\end{array}$ & $\begin{array}{c}-2.662 * * \\
(0.255)\end{array}$ \\
\hline Age & $\begin{array}{c}0.005 \\
(0.003)\end{array}$ & $\begin{array}{l}0.007 * \\
(0.003)\end{array}$ \\
\hline Respondent sex & $\begin{array}{c}0.323 * * \\
(0.057)\end{array}$ & $\begin{array}{c}0.229 * * \\
(0.057)\end{array}$ \\
\hline Two years of college ('Baccalauréat +2 ') & $\begin{array}{c}0.134 \\
(0.107)\end{array}$ & $\begin{array}{c}0.117 \\
(0.104)\end{array}$ \\
\hline Three years of college ('Baccalauréat + 3') & $\begin{array}{c}0.341 * * \\
(0.118)\end{array}$ & $\begin{array}{c}0.320 * * \\
(0.116)\end{array}$ \\
\hline Four years of college ('Baccalauréat +4 ') & $\begin{array}{c}0.327 * * \\
(0.115)\end{array}$ & $\begin{array}{l}0.237^{*} \\
(0.113)\end{array}$ \\
\hline Five years of college ('Baccalauréat +5 ') & $\begin{array}{c}0.555^{* *} \\
(0.099)\end{array}$ & $\begin{array}{l}0.400 * \\
(0.099)\end{array}$ \\
\hline Ph.D. ('Doctorat') & $\begin{array}{c}0.464 * * \\
(0.157)\end{array}$ & $\begin{array}{c}0.284 \\
(0.155)\end{array}$ \\
\hline High school economics only & $\begin{array}{c}0.055 \\
(0.103)\end{array}$ & $\begin{array}{c}0.029 \\
(0.101)\end{array}$ \\
\hline College economics & $\begin{array}{c}0.228 * * \\
(0.076)\end{array}$ & $\begin{array}{c}0.134 \\
(0.076)\end{array}$ \\
\hline Personal interest for economics & $\begin{array}{c}0.180 * * \\
(0.051)\end{array}$ & $\begin{array}{c}0.143^{*} \\
(0.050)\end{array}$ \\
\hline Use of economic concepts in daily life & $\begin{array}{c}0.046 \\
(0.032)\end{array}$ & $\begin{array}{c}0.016 \\
(0.032)\end{array}$ \\
\hline Executive & $\begin{array}{c}-0.081 \\
(0.114)\end{array}$ & $\begin{array}{l}-0.106 \\
(0.112)\end{array}$ \\
\hline Employee & $\begin{array}{c}-0.335^{*} \\
(0.147)\end{array}$ & $\begin{array}{c}-0.325^{*} \\
(0.144)\end{array}$ \\
\hline Self-employed & $\begin{array}{c}-0.002 \\
(0.178)\end{array}$ & $\begin{array}{c}0.032 \\
(0.174)\end{array}$ \\
\hline Professor & $\begin{array}{c}-0.102 \\
(0.171)\end{array}$ & $\begin{array}{c}-0.158 \\
(0.167)\end{array}$ \\
\hline Student & $\begin{array}{c}0.121 \\
(0.123)\end{array}$ & $\begin{array}{c}0.095 \\
(0.121)\end{array}$ \\
\hline Knowledge in economics & & $\begin{array}{c}0.022 * * \\
(0.003)\end{array}$ \\
\hline $\mathrm{F}$ & 12.457 & 15.650 \\
\hline $\mathrm{R}^{2}$ & 0.125 & 0.160 \\
\hline $\mathrm{R}^{2}$-adj. & 0.115 & 0.150 \\
\hline $\mathrm{N}$ & 1,410 & 1,410 \\
\hline
\end{tabular}

Two-tailed tests. Standards errors are in parentheses. 
ESSEC Business School Avenue Bernard Hirsch BP 50105

95021 Cergy-Pontoise Cedex France

Tél. + $33(0) 134433000$

Fax $+33(0) 134433001$

www.essec.fr

ESSEC Executive Education

CNIT BP 230

92053 Paris-La Défense

France

Tél. +33(0)146924900

Fax +33(0)1 46924990

http:l/formation.essec.fr

ESSEC Business School

Singapore Campus

100 Victoria Street

National Library Building \# 13-02

Singapore 188064

essecasia@essec.fr

Tél. +65 68849780

Fax +6568849781

www.essec.edu

\section{Informations}

Hanane Rahmoune +33 (0)134433358

rahmoune@essec.edu

www.essec.fr

research.center@essec.fr

ISSN 1291-9616 